\section{IMPROVING NARRATIVE WRITING ABILITY BY USING PICTURES}

Indrawaty Asfah

Universitas Negeri Makassar

Email: indrawaty.asfah@unm.ac.id

http://ojs.unm.ac.id/index.php/Insani/index

Abstrak. Penelitian ini bertujuan untuk meningkatkan kemampuan menulis narasi untuk siswa SMP. Subjek penelitian ini adalah 32 siswa kelas VII A SMP Bayangkara Makassar. Pembelajaran dilakukan dengan menggunakan gambar sebagai media. Pengumpulan data menggunakan observasi, rubrik penilaian, wawancara, jurnal, dan foto untuk dokumentasi. Hasil penelitian menunjukkan bahwa penggunaan warna cerah, menarik, sederhana, gambar yang mudah dipahami sebagai media dan disampaikan dalam presentasi terbaik, dapat meningkatkan kemampuan menulis narasi siswa.

Kata Kunci: Media, Media Gambar, Bahasa Inggris.
INDONESIAN

JOURNAL OF

EDUCATIONAL

STUDIES (IJES)

\section{E-ISSN: 2621-6744 \\ P-ISSN: 2621-6736}

Submitted: March, $23^{\text {th }} 2019$

Accepted : May, $7^{\text {th }} 2019$

Abstract. This study aims to improve the ability to write narratives for SMP or Junior High School students. The subjects of this study were 32 students class VII A SMP Bayangkara Makassar. Learning is carried out using pictures as the media. Data collection uses observation, assessment rubrics, interviews, journals, and photo for documentation. The results of the study show that the use of radiant color, attractive, simple, easy to understand pictures as a media and delivered in the best presentation, can improve students' narrative writing. 


\section{INTRODUCTION}

Writing is an integrated language skill. Writing skill is a person's ability to express ideas and feelings to other parties through written language. Writing skills are need in all fields of word. Often, students that can write well in Indonesian may nor produce the same quality of writing in English. The reason for this is that they may find is difficult to express their ideas in writing. This may cause low productivity in producing a written piece of work. In reality, students writing skills are still low.

Learning to write is the most difficult ability to mastered by students compared to other language skills. In addition, learning writing has not been encouraged as much as the other skills in Junior High School. One of the supporting facts is the teaching of writing condition in class VII A at SMP Bayangkara Makassar. Based on the initial observations, it was found that students have low motivation and ability to write narratives. This is indicated by complaints when students are assigned to write in English. In addition, the students' ability to write is still lacking. This is evidenced by the students composition results which only achieve an average score of 60 .

The students' ability to write narratives can be improved by fixing composition aspects that become students' weaknesses in writing. One measure that can be taken is to use media. Media is an intermediary or delivery message from sender to recipient of the message (Arief 1996:6). For this particular study, pictures are used as the media. This media was chosen with the consideration that images are the most commonly used, affordable, easy to remember by students, can show objects that may not be possible to be brought in the classroom, and are relevant to students' characteristics and achieving the basic competences. Moreover, pictures can make the teaching process easier for teachers to deliver and students easier to remember what they see, develop creativity and imagination. One of the main functions of learning media is as teaching aid that influences the climate, conditions, and learning environment that is organized and set up by the teacher (Azhar 2004:15).

A writing is basically an embodiment of the results of reasoning. This reasoning is related to the process of pouring out the main ideas to be developed into writing. Every writer must be able to pour ideas carefully into writing. One way that can be used to spark ideas is to use pictures as the learning media. Using such media can improve students' ability to compile stories based on sequences of images in order to make it into a complete narrative essay (Levie and Lents in Azhar 2004:16). In line with this, Azhar (2004:5) stated that the benefits of using pictures as learning media can improve the ability to write stories based on the series of images that had to be organized into a complete, coherent narrative essay and can improve students' ability to use spelling and punctuation correctly.

Based on the above explanations, the research problem is how learning using picture as the media can improve the ability to write narratives of students class VII A SMP Bayangkara Makassar. This research was conducted 
with the aim to help improve the ability to write narratives. The results of this study are expected to be useful for English teachers, especially those that intend to use pictures as the learning media in teaching narrative writing and intend to improve the quality of English subjects.

\section{RESEARCH METHOD}

This is a classroom action research. The subjects of the research are students class VII A with 32 students (16 female and 16 male). Class VII A is categorized as a class with the lowest level of student ability from the three VII classes in SMP Bayangkara Makassar. This research was conducted from September 2017 to April 2018. This research was conducted in two cycles. Each cycle went through the planning, action and observation, and reflection phase. The action taken to solve the research problem is the use of picture as media with the following steps. First, the teacher explains about the media that will be used. Second, students identify a series of images. Third, students compile a series of pictures. Fourth, students discuss the series of images randomly to make narratives. Fifth, students present the results of their group discussions. Sixth, display all the work of students based on groups. Seventh, determine students' best work by giving rewards.

There are two indicators that are set as a reference for the success of this study. First, the indicator of the success of the use of image media if all students have been able to be active and able to openly be involved in expressing thoughts regularly and enthusiastically following the stages of learning with pictures as media. Second, if the ability to write narratives of students of class VII A SMP Bayangkara Makassar reaches an average score of 75 or more.

As per the data collected, the instruments used are: format evaluation, assessment rubrics, interviews, journals, and photo for documentation. There are two observation format used as an instrument for collecting qualitative data which are the teacher observation format and the student observation format. Student writing assessment rubrics was used as quantitative data collection instruments. The components include: (1) determining themes, (2) developing narratives, (3) basic principles of narration, (4) word choice, (5) sentence effectiveness, and (6) spelling and punctuation The collected data is analyzed quantitatively (outcome assessment) and qualitatively (process assessment).

\section{RESULTS AND DISCUSSION}

This research was conducted in two cycles. Learning in the first cycle takes place in two meetings. Meanwhile, in cycle II, learning takes place in two meetings. Each meeting has three activities namely initial / opening activities, core activities / material exploration, and final / closing activities. The core activity is learning to write narratives by using picture as media. In each meeting, both cycle I and cycle II, utilizes the use of serial images that are attractive, colorful, simple, easy to understand, and give an overview of objects both living things and places. The discussion of results is presented as follows. 
Cycle I Qualitative data in the form of a description of students and teachers activities during the two meetings was obtained from the results of observational records. This was strengthened by the results of photos documented. Based on the observattion results of learning carried out on the implementation of the first action, the teacher opens learning with apperception and arouses student learning motivation to take part in the lesson and explains goals and themes of learning. Next, the teacher gives students an initial understanding of how to make an essay in the form of a narrative.

During the learning process when using pictures as the media, seven students activities were observed including (1) listening and paying attention to the teacher's explanations actively, (2) identifying serial images given by the teacher, (3) arranging the pieces into sequences based on the chronology of events, (4) discussing the results of identifying images in groups, (5) presenting the results of group discussions and making suggestions on the results of other group discussions, (6) displaying all students work in groups, and (7) determining students' best work.

Learning cycle I was felt not optimal, both from the process and results. From the process, the teacher has not fully provided explanation to students and students did not fully grasp about learning to write narratives using pictures. Based on the results of the analysis and evaluation of the actions taken by the teacher as well as the responses given by the students, it was found that perceived behaviors that were not optimal could be the cause of learning failure. The words chosen were not appealing. Students were not able to develop effective sentences that can reveal and catch messages to make communication effective, and almost all students are not ready for presentation because of unclear instructions from the teacher.

From the composition results, the average score of writing narratives with picture as media reaches 68.75. The implementation of the first and second meetings of the first cycle has not yet reached the specified success indicators, which is reaching 75 or more. Students who do not understand writing narratives with media images showed an average score of 19.53 or in the fairly good category. In the aspect of narrative development, the average score is 17.19 or in the good category. Meanwhile, the aspect of basic principles of a narrative obtained a mean value of 13.50 in the good category. Good categories are also obtained in the aspect of word choice which is in the average score of 9.09. The effectiveness of sentences aspects obtained an average value of 6.13 or good category. The last aspect is spelling and punctuation with a mean score of 3.31 in the unfavorable category.

Based on the tendency of the data, it can be concluded that the results obtained by students did not meet the standards, as the scores obtained were not as expected. Because learning outcomes have not reached the specified success indicators of 75 and/or more, the research continued to cycle II. The use of picture as media focused on five aspects in the activity, namely (1) arranging the pieces of the images into sequences based on the chronology of events, (2) discussing the results of identifying images in groups, (3) presenting the results 
of group discussions and giving suggestions on the results of other group discussions (4) displaying all students' work in groups, and (5) determining students' best work.

Cycle II in the second cycle of learning it appears that most students are ready to take part in learning. By implementing learning using pictures as media along with varied learning processes, students are more enthusiastic and appear to be more active. This is because students already have an understanding of picture as media and can arrange pieces of pictures into sequences based on the chronological events compared to previous learning.

Based on the results of observations and seven activities, it has experienced an increase from the previous learning. This happened in the activity of listening and paying attention to the teacher's explanation actively and identifying serial images given by the teacher. There are five activities that are felt not optimal which can cause learning failure. These activities include (1) arranging the pieces of the image into sequences based on the chronology of the events, (2) discussing the results of identifying images in groups, (3) presenting the results of group discussions and making suggestions on the results of other group discussions, (4) displaying all students' work in group form, and (5) determine the best work of students.

Based on the results of the analysis and evaluation of the actions taken by the teacher and the responses given by the students in the second cycle, it was concluded that the activity of writing narratives with the pictures as media took place optimally. Learning carried out in two meetings in the second cycle was felt to be optimal, both in terms of the process of preparation and results. In terms of process, students are able to adapt themselves to narrative learning activities with pictures as the media. Students' attention is better than before. They seem very serious in writing. This learning greatly facilitates students in writing narratives. They also do not feel tired of doing this activity. This is evidenced by the willingness and sincerity of the students in doing the task given by the teacher. In learning, the students seem to be happy and eager so that by themselves they are active and creative to enhance the potential that exists in them. This stage can also encourage less creative students in writing narratives.

Meanwhile, the average score of writing narratives with picture as media reached 75.78 from the second cycle. This means that the second cycle has achieved the specified success indicator, which reaches a value of 75 and/or more. The ability of students in each aspect of the literary writing of the narrative showed that the aspects of determining the theme obtained 21.09 or in the good category. In the aspect of narrative development, the average score is 18.75 or in the good category. Meanwhile, the basic principle of a narrative obtained an average value of 14.84 in the good category. A good enough category is also obtained in the aspect of word choice with 10.41. The sentence effectiveness made by students obtained an average score of 6.94 or a fairly good category. The last aspect is spelling and punctuation with an average score of 3.75 which is in the good category. Because the class was able to 
reached the specified success indicator, which is 75 or more, it was decided to end the study in this second cycle. Thus, it can be concluded that the application of pictures as media can improve the ability to write narratives of class VII A SMP Bayangkara Makassar.

Based on the results of the analysis and evaluation of the actions and student learning outcomes, it can be seen that the pictures as media can improve the writing of student narratives both in cycle I and cycle II. Based on the tendency of the data obtained, it can be concluded that there is an increase in students' ability to write narratives after participating in learning, both in cycle I and cycle II. In cycle I, learning is carried out in two meetings. Even though it has not yet achieved the specified success indicators, student learning outcomes for writing narratives show an increase from the first meeting to the second meeting. In Cycle II, learning is carried out in two meetings. Student learning outcomes for writing narratives also showed improvement from the first meeting to the second meeting. At the second meeting, indicators of success can be achieved.

The failure to reached the indicators of success in the first cycle seem to be caused by not applying the pictures as media to its maximum usage. Cycle I and Cycle II data show that students' abilities are higher in making narratives. This is relevant to Darmadi (1996) that students' competence in writing narrative essays can be improved by fixing all the things that are students' weaknesses in writing. A writing is basically a manifestation of student reasoning results. Azhar (2004: 15) argues that the advantage of using image media is that students can improve their ability to compile stories based on sequential images so that they are intact narratives, can improve students' ability to combine sentences into coherent narrative essays using appropriate conjunctions, and can improve students' ability to use spelling and punctuation correctly in essays.

Based on the results of journals and interviews, it turns out there are still many students who experienced difficulties in writing narratives. Student responses to the using of pictures as learning media were very good. They respond positively and are happy with the media used. The material presented is more interesting and in-depth. Based on the results of learning in the first cycle, it became the basis for researcher to make improvements in the actions to be implemented in the second cycle of learning. The actions taken by the researcher are to make improvements to the learning media used, improvement in learning methods, group activities are transformed into individual activities, the teacher goes from one student to another to give guidance and direction to students who seem somewhat confused in writing narratives.

The results of observations made when students take part in learning to write narratives with media images in the second cycle showed changes in students behavior. This can be known from students who did not follow the learning well. In the second cycle, students began to follow and carry out learning activities applied by researchers well, so that it can be seen that students are able to adjust to the learning activities of writing narratives with 


\section{Indonesian Journal of Educational Studies Vol.22, No.1, June 2019}

media images. Student attention is better than before. They are very serious in learning. This is proven when students love to learn to write narratives. This fact is evidenced from the results of the cycle I and cycle II tests with the increasing score in writing narratives.

Journal results and cycle II interviews also showed pleasant results. According to them, learning with pictures as media greatly facilitates students in learning to write narratives and was not boring. This is evidenced by the willingness and sincerity of students in doing the assignments given by the teacher. The use of pictures as media used by teachers in learning to write narratives turns out to provide positive benefits and changes for students. Students were serious in learning and the results are increasing.

Based on the range of data analysis and learning situations, it can be implied that there is progress in students. The progress experienced by students leads to better behavior. Students are more enthusiastic and serious in learning. Thus it can be concluded that writing narratives with pictures as media can help students to express their ideas in writing narratives. Students also get new experiences in writing narratives and these experiences make students more motivated to write effective narratives. Furthermore, based on an analysis of the data collection instruments, the results obtained are in the form of continuity between one data and another data both in form of test and nontest. This shows that the results of this assessment are explained based on the actual conditions that occur. Tests, observations, interviews, journals, and photo documentation are a series of data collection instruments that have revealed the relationship or continuity.

In terms of narrative writing results, there is an increase in the narrative writing in the first cycle. Students reached an average of 68.75. Meanwhile, the results of the assessment in the second cycle reached an average score of 75.78 .

The results of the assessment of narrative writing in the first cycle to the second cycle increased $10.23 \%$. This increase is reflected in the learning outcomes of students who can determine the theme and mandate very well, compile details in the sequence and use dialogue in interesting presentation, understand flow components, characterization, background, point of view, and selection of detailed events was arranged very well and complete, arrange stories based on sequences of pictures in order to become a complete narrative essay, can combine sentences into coherent narrative essays using appropriate conjunctions, and can use spelling and punctuation correctly in essays. Through pictures as media in writing narratives, students are more enthusiastic in participating in learning.

\section{CONCLUSIONS}

In line with the problems discussed, the purpose and scope of this study and based on the findings of this study and its discussion, the following conclusions can be put forward. The use of radiant, interesting, simple, easy-tounderstand, and giving pictures of objects both living things and places in learning can improve narrative writing. Learning by using pictures as media 
consists of seven student activities which include: (1) listening and paying attention to the teacher's explanations actively, (2) identifying a series of pictures given by the teacher, (3) arranging the pieces into sequences based on the chronology of events, (4) discussing the results of identifying images in groups, (5) presenting the results of group discussions and make suggestions for the results of other group's discussions, (6) displaying all student work in group form, and (7) determining students' best work. The narrative writing skills of class VII A SMP Bayangkara Makassar after participating in learning to write narratives with pictures as the learning media has experienced an increase. The increase can be seen from the changes in the average score from cycle I to cycle II. In the first cycle, the score obtained an average of 68.75 while the second cycle the score reached an average of 75.78. In the description of this research findings, it had revealed about the improvement in narrative writing ability with pictures as media of student class VII A SMP Bayangkara Makassar. However, this study cannot solve all the problems related to writing a good narrative. Further research should be done to explore aspects of narrative writing that have not been discussed in this study, also comparing it with students that had different basic competencies and with a larger and variety of sample size.

\section{REFERENCES}

Arief, S. (1996). Media Pendidikan: Pengertian, Pengembangan, dan Pemanfaatannya. Jakarta: PT Raja Grafindo Persada.

Azhar, A. (2004). Media Pembelajaran. Jakarta: PT Raja Grafindo Persada.

Darmadi, K. (1996). Meningkatkan Kemampuan Menulis. Yogyakarta: Andi Yogyakarta.

Eggen, P amd Kouchack, D. (1996). Strategies for Teachers: Teaching Content and Thinking Skills. Boston: Sllyn and Bocon

Moleong, L. (2002). Metodologi Penelitian Kualitative. Bandung: Remaja Rosdakarya. 